\title{
Teaching Practices in Mexico: A Way to Understand Mexican English Learners in the United States
}

\author{
Marcela de Souza \\ California State University, Fullerton
}

U. S. A.

This paper presents findings from a qualitative study conducted in fifth and sixth grade classrooms in five public schools in Guadalajara, Mexico, in June of 2009. The goal of the study was to learn about current instructional and institutional practices in a region with high migratory rates to the United States, with the express purpose of understanding the type of school experiences Mexican-born English learners usually gain before entering the American school system. Findings include close teacherstudent relationships, a strong respect for teachers, school-wide disciplinary chants and in-class routines in which all students participate, and the integration of Enciclomedia in the classroom.

\author{
Literature Review \\ Theoretical Framework \\ Methodology \\ Data Analysis \\ Findings \\ Implications \\ Conclusion \\ Acknowledgments \\ Notes \\ References
}

American K-12 public school teachers are entrusted with educating an increasing number of English language learners in the mainstream classroom. The majority of these students are Spanish-speaking (Fry, 2007), and close to $70 \%$ are of Mexican descent (Ramírez \& de la Cruz, 2003; Bean et. al, 1994; Kao \& Tienda, 1995). In order to succeed academically, these students not only need to learn a new language, but also adjust to new interaction patterns, forms of address, norms of conduct, and cultural expectations. Although research shows that English learners can learn best in a classroom where they feel welcome, safe, and appreciated, and when their home culture and first language are validated, it is imperative to take an in-depth look at other factors that mediate minority academic achievement so that we can maximize their opportunity for success, as it is well documented that Hispanic students, along with African Americans, have the highest high school dropout rates (Cameron \& Heckman, 2001; Greene, 2001; Loftstrom, 2007; Reyes \& Paredes Scribner, 1995). 
A high percentage of Mexican immigrant students experience difficulties adapting to school life in this country. In addition to limited or no proficiency in English, at least in the beginning of their stay in the United States, they usually possess very little knowledge about the American educational system (Friedlander, 1991). Keeping up with the demands of schoolwork in this era of accountability when they are expected to perform at levels comparable to those of their native-English-speaking peers within an arguably short amount of time upon arrival can take a toll on them, making the stages of culture shock that immigrants are known to experience (Schumann, 1986) more difficult to overcome. These students find themselves lost in American schools where the teaching practices often differ from those with which they were familiar. As a result, many of them feel disoriented and overwhelmed by so many changes, which causes their anxiety level to increase. Krashen $(1981,1982)$ has noted that this type of anxiety hinders their acquisition of the English language.

Hispanics, the largest minority group and the fastest growing population in the United States, continue to struggle academically (American Council on Education, 2010; Gándara, 2009). Despite having made educational gains since the 1980s, Hispanic students have higher high school dropout rates and lower high school completion rates than their non-Hispanic White peers (NCES, 2003). The Education Commission of the States (2010) reports that $36 \%$ of the foreign-born population comes from Mexico and Central America, and although school completion rates vary by country of origin, age at time of arrival, and immigration status, Mexican students still lag behind (Ruiz-deVelasco \& Fix, 2000). The long-standing, nation-wide achievement gap separating poor and ethnic minority students from middle-class and White students has not improved over the last two decades (Bok, 2003; Genesse et al., 2005; Ladson-Billings, 2006). Since we already know what challenges these students face, we need to keep focusing on ways they may overcome these challenges. Learning about the school culture Mexican English learners were used to before entering the American school system may just be one of those ways. With this knowledge, teachers in the United States can bridge cultural gaps and help immigrant children feel more connected to American school life.

\section{Literature Review}

Non-native English speakers account for $18 \%$ of the U.S. population (U.S. Census Bureau, 2003c), and it is estimated that by 2025 one in four students will be initially classified as English learners (NCELA, 2007). Since the No Child Left Behind Act came into effect in 2001, fewer English learners have been able to secure a high school diploma because passing the high school exit exam has been beyond their reach (Biancarosa \& Snow, 2004). Presently, 71\% of eighth graders who are English learners test below grade level in reading and math (NCES, 2005).

Several explanations have been attempted to account for the academic achievement of some ethnic minority students and the underachievement of others. One such explanation is known as "cultural mismatch" and maintains that some of the skills acquired in the home culture may be transferable to the new culture while other 
home-based skills may be neither expected nor valued by members of the target culture. In this view, achievement is a function of the interaction between two cultures. Leading experts in the field such as Delgado-Gaitán and Trueba (1991) and Díaz-Rico and Weed (2010) have asserted that there is insufficient integration of students' culture into the mainstream curriculum and that it is important to develop culturally relevant teaching practices and learning materials. Similarly, other researchers have pointed out the benefit of incorporating elements of the students' home culture into the curriculum (Richards, Brown, \& Forde, 2004), which goes beyond acknowledging holidays and sharing traditional recipes. When the cultures represented in the classroom are equally valued, students can be engaged more effectively and learning can be maximized.

English learners are faced with the double challenge of acquiring a second language while keeping up with grade-level content in a new cultural environment. They must acclimate not only to the dominant culture of mainstream society, but also the particular culture of the school they attend. Many of the new social norms and expectations are different from what they were familiar with during their prior formal schooling. American mainstream culture has traditionally reflected European American values (Gay, 2006; Hollins, 1996), but many present-day immigrant students do not identify with those values. Cultural clashes and misunderstandings may occur as "cultural differences often bring with them different notions of how students learn best; how they behave; what kinds of interventions can help them meet the school's expectations; and what roles teacher, student, and parent should play" (Trumbull \& Rothstein-Fisch, 2008, p. 63).

Mexican students may also feel confused, isolated, and cognitively overloaded. Shutting down or withdrawing may be a way for them to cope with such a culture shock (McLaughlin et al., 2002). Imposing the American school culture on them without regard for their home culture can clearly exert additional stress (Grossman, 1995), which will negatively impact their learning. Therefore, teachers working with these students need to implement teaching practices that are in tune with students' cultures (Trumbull \& Rothstein-Fisch, 2008) and that view their native language as an asset. This is not a novel idea since it has been advocated for decades now, but what has not been the focus of research is the specific school culture that foreign-born students bring with them to the classroom.

Even the most experienced teacher equipped with a wide array of researchbased instructional strategies will prove ineffective in educating English learners if the students' background knowledge and resources are not taken into consideration when lesson planning, delivering instruction, and both developing and administering assessments. Immigrant students are naturally shy when they are new at an unfamiliar school in a foreign country. Cummins (2001) claims that schools that accept and appreciate the home languages and cultures of students help them develop additive bilingualism and strong identities, whereas schools that allow for disrespect and discrimination to take place hinder both their social and emotional development (as cited in Díaz-Rico \& Weed, 2010, p. 11). When teachers get to know their students and find ways to incorporate their home-based expertise or "funds of knowledge" (Moll, et al., 1992; Moll \& Gonzalez, 2004) in the classroom, students are better able to make connections between topics and across languages, thus maximizing their learning. 
Clearly, there is no shortage of research on English language learners. In general, the literature confirms the need for culturally responsive curricula. However, research on Mexican schooling is very limited. At the time this study was conducted, very few relevant studies were identified. Here I discuss three studies. First, during the summers of 2003 and 2004, Escamilla, Aragon, and Fránquiz (2009) led a two-week study in two public primary schools in Puebla, Mexico, in which American teachers, paraprofessionals, and administrators participated. Data analysis revealed that the participants expressed deficit views about Mexican schools, which the authors claim stemmed from "the unconscious and unexamined belief among U.S. teachers in the superiority of U.S. schools" (p. 271), the material culture (Johnson, 1980) they had internalized in their teacher education programs, and the assumption that what we refer to as "best practices" apply to all children.

Second, two school sites in a small city in south central Mexico (a public elementary school serving the children of working-class parents and a Montessori school attended by middle-class students) provided Jiménez, Smith, and Martínez-León (2003) the opportunity to examine current uses of language and literacy practices by teachers, students, and administrators in beginning levels (preschool through first grade) and intermediate grades (fourth through sixth). The authors found an overt concern with students' written language, electronic and print texts that had originated in countries such as the United States, and the view of some students' linguistic capital as a deficiency. The authors examined literacy practices inside and outside the schools and learned that Mexican teachers appear to focus more on form than on meaningful expression and that writing is highly controlled while oral communication is not. Correctness of form, as prescribed by the Real Academia Española (Spanish Royal Academy), takes precedence over meaningful expression.

Third, researchers McLaughlin and Bryan (2003) frequently visited two rural Mexican elementary schools over a three-year period to learn about teaching practices that aim at increasing students' social responsibility. Although the authors do not argue that we should adopt the model of social work on which the curriculum is based in those two rural schools in Mexico, they suggest that educators in the United States should give more thought to the social curriculum, that is, the teaching of positive attitudes and social values.

The present study focused on Mexican students in interaction with their teachers and peers in the social context of the classroom. Therefore, key principles of sociocultural theory, the model of cultural discontinuity (Delgado-Gaitan \& Trueba, 1991; Ogbu, 1994), and the notion of funds of knowledge (Moll et al., 1992; 2004) provide the conceptual lens to examine the teaching and learning practices observed at the five participating schools in Guadalajara, Mexico.

\section{Theoretical Framework}

Although the academic success of English learners depends on multiple factors (personal, societal, and political), the social context plays a major role. Socioculturalists argue that individuals must be immersed in socially mediated activities in order to learn. 
This belief stems from Vygotsky's (1978) view of full cognitive development as being dependent on social interaction. In his view, "every function in the child's cultural development appears twice: first, on the social level, and later, on the individual level; first, between people (interpsychological) and then inside the child (intrapsychological)" (p. 57). Therefore, all knowledge is socially and culturally constructed.

Moll and his colleagues contend that foreign-born students bring to the classroom procedural knowledge developed through observation of family members performing household tasks in which they assist. Teachers can draw on and build upon this cultural knowledge to enhance these students' academic development in U.S. classrooms. In doing so, teachers can ameliorate cultural differences and lessen the effect of cultural discontinuity, which is believed to occur when the beliefs, values, norms, and practices an ethnic minority student experiences at home are not taught, expected, or appreciated at school. The tension and miscommunication that may result from this cultural mismatch are inimical to academic achievement.

The core curriculum, the teaching methods, and the school organization of the United States are unfamiliar to most immigrant children. To facilitate their adjustment to the new environment, rules, and expectations, all teachers need to acknowledge, validate, and integrate into their lessons - to any extent possible - the specific cultural knowledge and home country school traditions that foreign-born students bring with them. Because language and culture are closely related, cultural barriers must be minimized in order for a second language to be acquired. With this in mind, the overarching goal of this study was to gain a good understanding of the type of instructional practices that are common in elementary schools in Guadalajara, Mexico, in order to help Mexican-born students bridge the differences and adapt to schools in the United States, thus increasing their chances to succeed academically in our school system.

\section{Methodology}

This research followed a qualitative approach and took place in Guadalajara, a state located in the central region of Jalisco off the Pacific coast of Mexico. Jalisco was chosen because it is one of the states with the highest migratory rates to the United States (Sañudo \& Wilhelm, 2008). According to a report commissioned by the California Department of Education (2007), nearly $50 \%$ of California Mexican migrants during 2003-2004 came from Jalisco, Michoacán, and Guanajuato. The city of Guadalajara was selected on the basis of contacts with school officials that the researcher was able to make in the months preceding the study.

This study sought to answer two overarching questions: (1) What are the most prevalent current pedagogical practices in Mexican schools? (2) What can we as educators in the United States learn from these practices? Although this study is part of a larger project, this article is based on data collected from five public schools in the Municipio de Guadalajara, Jalisco, during a 12-day visit in June, 2009. Fifth and sixth grade classrooms were observed. Informal interviews were carried out with teachers, 
school administrators, and support staff before the beginning of the school day, during recess, at lunchtime, as well as after school. Additional "directed conversations" (Lofland \& Lofland, 1984) with researchers from the Instituto Superior de Investigación y Docencia para el Magisterio (ISIDM) continued at a local coffee shop, a location of their choice. The purpose of this meeting was to further ascertain the social and cultural context of the data gathered at the schools. Photographs of each school campus and of students both at work and at play were taken with permission of the school administrators. Artifacts, such as student projects and class materials, were collected to help create a detailed picture of the context of school and its literacy development practices.

\section{Data Analysis}

Data from interviews with adults and field notes were closely analyzed and crossreferenced for similarities, although the bulk of the data came from copious field notes from each classroom observation. Class size in the five schools ranged from a minimum of 24 to a maximum of 42 students (see Table 1). The number of students per school ranged from 446 to 1,031 , and most students were between the ages of 10 and 12 . The chart below shows information pertaining to each participating school. For confidentiality purposes, only the teachers' first initials are given and the schools' identification numbers have been changed.

Table 1. Sites and Participants

\begin{tabular}{|c|l|l|l|l|l|}
\hline Date & Time & \multicolumn{1}{|c|}{ School } & Grade & Teacher & \multicolumn{1}{|c|}{ Number of Students } \\
\hline $6 / 01 / 09$ & P.M. & Urbana \#1 & $5^{\text {th }}$ & Maestra C. & 30 boys \\
\hline $6 / 02 / 09$ & A.M. & Urbana \#1 & $6^{\text {th }}$ & Maestra L. & 42 girls \\
\hline $6 / 02 / 09$ & A.M. & Urbana \#1 & $6^{\text {th }}$ & Maestra Y. & 30 girls \\
\hline $6 / 02 / 09$ & P.M. & Urbana \#2 & $6^{\text {th }}$ & Maestra A. & 24 boys \\
\hline $6 / 03 / 09$ & A.M. & Urbana \#3 & $5^{\text {th }}$ & Maestra J. & 35 boys and girls \\
\hline $6 / 03 / 09$ & A.M. & Urbana \#3 & $5^{\text {th }}$ & Maestra L. & 36 boys and girls \\
\hline $6 / 03 / 09$ & P.M. & Urbana \#4 & $5^{\text {th }}$ & Maestra B. & 30 boys and girls \\
\hline $6 / 03 / 09$ & P.M. & Urbana \#4 & $6^{\text {th }}$ & Maestra M. & 40 boys and girls \\
\hline $6 / 03 / 09$ & P.M. & Urbana \#4 & $6^{\text {th }}$ & Maestro A. & 35 boys and girls \\
\hline $6 / 03 / 09$ & P.M. & Urbana \#4 & $6^{\text {th }}$ & Maestra L. & 30 boys and girls \\
\hline $6 / 04 / 09$ & A.M. & Urbana \#5 & $6^{\text {th }}$ & Maestra N. & 30 boys and girls \\
\hline $6 / 04 / 09$ & A.M. & Urbana \#5 & $6^{\text {th }}$ & Maestro H. & 25 boys and girls \\
\hline
\end{tabular}




\section{Findings}

Several interesting findings emerged from the data analysis. Although teachers in Mexico have the academic freedom to choose the most appropriate methods to deliver their instruction, common classroom practices were apparent around the school at each site. Such practices include a warm teaching style, a preference for direct instruction, a disciplinary protocol implemented as needed, the integration of short relaxation exercises between major in-class activities, and a technology-infused curriculum through Enciclomedia. These practices were observed in the context of plain classroom settings where students displayed a high level of respect for their teachers.

Most of the female teachers that were observed implement a nurturing teaching method. They often address their students with affection employing expressions such as "corazón" (sweetheart), "mi amor" (my love), "hijos" (my children), and "jovencitos" (young ones). The implicit message students receive is that no academic task is beyond reach provided they apply themselves and accept help when needed. Teachers' expectation of their students is high, and strong work ethics are both modeled and expected by the teachers. A sense of community and responsibility for the entire group is apparent in every classroom. If a problem arises, everything stops until the students can collaboratively find a solution.

Although cooperative learning (Kagan, 1986) and direct instruction were observed, the emphasis was on direct instruction. Teachers made frequent comprehension checks, cuing students before calling on them: "Listo Miguel porque te voy a preguntar" (Are you ready Miguel because I am going to call on you). As needed, teachers would give demonstrations or step-by-step directions on how to solve math problems, create a newsletter, or complete origami projects. At the start of class the teacher would review what had been covered the day before, thus helping students make connections between past learning and the content concepts they were about to learn. When students were assigned to table groups, discussion with their classmates helped bring depth to the subject in question and gain new insights from multiple perspectives. Supplementary materials, such as manipulatives, were used in math classes. A variety of grouping configurations were observed. Pairs, triads, and small groups allowed for student-student interactions, encouraged collaboration, and promoted multiple views on the topic under study.

Students responded well to the responsibilities placed upon them, and the teacher's genuine praise helped reinforce a good sense of self-worth. Clearly, the focus was on academic learning, yet the student-teacher relationship was warm. A strong respect for teachers, school administrators and staff members was apparent. At these schools, the majority of students address their female teachers as "Maestras" while they call their male teachers "Profes" (short for "Profesor"). Even though students were fully engaged and seemed intently trying to learn the material, from time to time they would lose focus and start talking with their peers about unrelated topics. On those occasions, the teacher was quick to implement a disciplinary protocol, which was in place in all classrooms. Participating in guided disciplinary chants helped the students quiet down 
and re-focus their attention to the task at hand. The following are two examples of such chants:
Uno, dos, tres.
One, two, three.
A la izquierda.
To the left.
A la derecha.
To the right.
Mirando al frente.
Look up front.
Manitas arriba
Hands up.
En los hombros
To the shoulders.
Arriba. Abajo.
Up. Down.
Candado en la boca.
Lock your mouth.

In both the morning and the afternoon shifts, students do not have a recess break for two and a half hours. Therefore, most teachers integrate into their lessons stretching and relaxation exercises that help students re-energize so that they can stay productive until the break. Below is the script for one of such exercises:

De pié. Inhalen. 1-2-3. Exhalen. Levanten los brazos. Arriba. Abajo. Arriba con los ojos cerrados. Arriba con los ojos abiertos. Siéntense. 1-2-3. A trabajar!

Stand up. Inhale. 1-2-3. Exhale. Hands up. Up. Down. Hands up with your eyes closed. Hands up with your eyes open. Sit down. 1-2-3. Let's work!

"El cartero" (the mail carrier) is a game one of the teachers played to change the pace in the classroom and get the students out of their assigned seats for a few minutes. The teacher would say: "Tengo una carta para los que tengan zapatos negros" (I have a letter for those who are wearing black shoes), and the students who could relate to that statement would have to find a new seat. As one chair was missing, one of the students would remain standing, and s/he would then become the mail carrier.

Students receive an hour a week of foreign language instruction in English. Bilingual education is not offered in public schools but is provided in both private English language academies and Montessori schools in large cities such as Guadalajara, Mexico City, and Monterrey. However, the majority of Mexican students who enter the American school system have attended public school, and as a result, their command of English is (very) limited. In addition to that, many low socioeconomic status (SES) Mexican students in the United States, as noted earlier, may exhibit values and behaviors that are not consistent with those expected, reinforced, and rewarded in mainstream American classrooms (Comer, 1984).

In all 12 classrooms where observations were conducted, technology was used to support both teaching and learning. Every classroom was equipped with Enciclomedia, an educational program that helps students learn complex concepts in easy and interactive ways. During an informal interview with Maestra N. at lunchtime, she explained that Enciclomedia had been implemented in all fifth and sixth grades across the nation since the 2003-2004 school year, an initiative of Former President 
Vicente Fox. This particular technology not only makes it possible for students to take virtual tours of museums, art galleries, national treasures, and wonders of the world, but it also gives them access to every single page in their textbook, which can be projected on a big screen in the front of the room.

The physical learning environments where classes meet are stark, pared down to the very minimum. In most classrooms the Mexican flag is displayed, and in some rooms there is a poster with the weekly schedule, expected norms of conduct, and/or influential historical figures like Miguel Hidalgo, the father of the country. Very few classrooms have a reading corner or a bookshelf. Course textbooks and workbooks are distributed at the start of class and collected right before the class is dismissed. Different grouping configurations were observed, although the conventional pattern was prevalent in most classrooms. An informal interview with school principals confirmed that American practices such as Saturday school and "back-to-school night" are not common in Mexican schools. The student services offered by the five participating schools do not include a detention center, after-school programs, student clubs, or a tutoring facility. At these schools there is no gymnasium, and therefore, physical education classes are held in the schoolyard.

The findings reported in this paper are based on direct classroom observations and informal interviews with teachers, school administrators, and support staff from five public elementary schools in Guadalajara, Mexico. While these are public schools in urban communities like many others in Guadalajara, they may be unlike other comparable schools in some ways. Consequently, the findings in this study cannot be generalized to all public elementary schools in Mexico.

\section{Implications}

Findings from this study can be useful to both beginning and experienced English as a Second Language teachers as well as sheltered content area teachers when planning lessons, developing class materials, and implementing instruction, particularly for Mexican immigrant students. A better understanding of cultural differences can lead to improved student-student and teacher-student interactions. Specific cultural information derived from the study can also help orient incoming immigrant Mexican students to their new learning environment. Additionally, these new insights can be valuable to teacher educators, professional development organizers, and learning materials developers.

All teachers entrusted to work with English learners need to be knowledgeable about the basic principles of second language acquisition and the impact that the home culture and first language have on the process of gaining academic proficiency in a second language. Culture permeates every aspect of life, so it must be taken into account when planning and delivering instruction. Tapping into these students' homebased "funds of knowledge" can facilitate the instruction of academic skills and content concepts, as it will allow the students to make explicit connections between home and school, existing knowledge and new learning. Sleeter (2008) states that diverse 
students "need teachers who can engage them academically by building on what they know and what interests them" (p. 214). García (1994) concurs, adding that teachers who can overcome cultural barriers can make a difference in the lives of Hispanic students. Just as many immigrant children develop as "cultural brokers" (Vasquez et al., 1994) and act as interpreters for their parents, teachers should become cultural bridges that connect the American school culture to these students' school culture, thus easing the transition and helping them acclimate to the expectations of the new educational system.

With an ever-increasing number of English learners in K-12 public schools nationwide, we cannot afford not to learn more about the prior schooling of these students or to re-evaluate the demands that we place upon them. For example, roleplaying and simulations are among American teachers' favorite ways of helping students learn by doing. To a foreign-born student, this may be an alien learning strategy, and s/he would therefore need an orientation to adjust to this type of activity. Since many Mexican-born students are used to choral work and being quizzed in front of their peers, teachers could give interactive lectures and periodically pose review questions, for which the students first write down the answer at their desks and then share it with their partner before raising their hands or response boards. This strategy enables the teacher to quickly check student understanding and clarify misunderstandings while keeping everyone involved. Another strategy that these students would find easy to use is "One say, all say" strategy (Pilon, 1987) in which a student reads aloud a definition on a card and everyone else responds in unison after hearing the teacher say "Everyone." Both these strategies are aligned with instructional practices with which Mexican-born students are most likely familiar.

Likewise, sociocultural differences need to be taken into account. Mexican children treat their elders with great respect, and this respect extends to their teachers. Although children in Mexico are expected to lower their eyes when an adult is reprimanding them, this behavior may be perceived as a sign of disrespect in the United States. In the same way, the fact that classrooms in Mexican schools tend to have very little on the walls may result in sensory overload when these students are placed in classrooms where every possible space on the walls is covered with posters and other educational materials (Mount-Cors, 2008). Another difference involves changing classrooms at the middle school and high school levels. In Mexican schools, teachers change classrooms. In the United States, students do.

\section{Conclusion}

We must build stronger connections with our Mexican students to help them feel more connected with their US-born teachers and peers. Before they can learn anything, they must feel welcome. This can be achieved by validating their home culture, native language, and previous school experiences. To this end, teachers must get to know their students to discover what they know and need. Regardless of social background and language of origin, they all have knowledge that comes from life experience that should be activated to maximize their learning. Much as Murrell suggests (2001), teachers must become "community teachers" by acquiring knowledge of the culture of 
the students they serve so they can "draw on this knowledge to create the core teaching practices necessary for effectiveness in diverse settings" (p. 52). With an understanding of their students' cultural norms, teachers will realize that what could be interpreted as "misbehavior" in the American classroom may be deemed appropriate behavior in the student's home school.

Culture is all-pervasive, and it affects learning. If we increase our awareness about the school culture many of our immigrant students grew accustomed to before immigrating to the United States, we will be better equipped to facilitate their transition to the American school system, develop culturally responsive teaching practices and learning materials, create optimal learning environments for all students, and improve the educational outcomes of students who are lagging behind. Prior knowledge is as essential to students in the learning process as it is to teachers in the teaching process. If we fail to recognize and integrate the cultural capital (Bourdieu, 1986) and the background knowledge our Mexican-origin English learners bring with them, we may be missing opportunities to help them adjust and succeed. In this view, teachers can become the cultural bridge that facilitates the connection between two worlds by ameliorating "cultural differences and cultural conflicts" (Delpit, 1995) that might be keeping their students from achieving their maximum potential.

\section{Acknowledgments}

The author wishes to thank Lic. María Edith López Melchor, Prof. Fernando García García, and Prof. Víctor Flores Márquez for faciliating her access to the schools.

\section{Notes}

1. Escuelas Urbanas 1 and 2 are single-sex whereas 3,4 , and 5 are co-ed. The morning shift starts at 8:00 A.M. and ends at 12:30 P.M. The afternoon shift begins at 2:00 P.M. and ends at 6:00 P.M.

\section{References}

American Council on Education (2010). New data indicate educational attainment continues to flat-line. Retrieved November 12, 2010, from http://www.acenet.edu

Bean, F. D., Chapa, J., Berg, R. R., \& Sowards, K. A. (1994). Educational and sociodemographic incorporation among Hispanic immigrants to the United States. In B. Edmonston \& J. S. Passel (Eds.), Immigration and ethnicity: The integration of America's newest arrivals (pp. 73-100). Washington, DC: Urban Institute Press.

Biancarosa, G., \& Snow, C. (2004). Reading next: A vision for action and research in middle and high school literacy. Report to the Carnegie Corporation of New York. Washington, DC: Alliance for Excellent Education. 
Bok, D. (2003). Closing the nagging gap in minority achievement. The Chronicle Review, 50(9), B20.

Bourdieu, P. (1986). The forms of capital. In J. Richardson (Ed.), Handbook of theory and research for the sociology of education (pp. 241-258). New York: Greenwood Press.

California Department of Education (2007). California migrant education program: Comprehensive needs assessment. Initial report of findings. Retrieved November 21, 2010, from http://www.cde.ca.gov/sp/me/mt/documents/cnareport.pdf

Cameron, S. V., \& Heckman, J. J. (2001). The dynamics of educational attainment for Black, Hispanic, and White males. Journal of Political Economy, 109, 455-499.

Comer, J. P. (1984). Home-school relationships as they affect the academic success of children. Education and Urban Society, 16, 323-337.

Cummins, J. (2001). Negotiating identities: Education for empowerment in a diverse society. Los Angeles: California Association for Bilingual Education.

Delgado-Gaitán, C., \& Trueba, H. (1991). Crossing cultural borders: Education for immigrant families in America. London: Falmer Press.

Delpit, L. (1995). Other people's children: Cultural conflict in the classroom. New York: The New Press.

Díaz-Rico, L. \& Weed, K. (2010). The crosscultural, language, and academic development handbook: A complete $\mathrm{K}-12$ reference guide $\left(4^{\text {th }}\right.$ ed.). Boston, MA: Pearson/ Allyn \& Bacon.

Education Commission of the States (2010). Improving Hispanic achievement: Implications for state policy. Retrieved November 12, 2010, from http://www.ecs.org

Escamilla, K., Aragon, L., \& Fránquiz, M. (2009). The transformative potential of a Study in Mexico Program for U.S. teachers. Journal of Latinos and Education, 8(4),270289.

Friedlander, M. (1991). The newcomer program: Helping immigrant students succeed in U.S. schools. Washington, DC: National Clearinghouse for Bilingual Education.

Fry, R. (2007). How far behind in math and reading are English language learners? Retrieved January 6, 2010, from http://pewhispanic.org/files/reports/76.pdf

García, E. (1994). Understanding and meeting the challenge of student cultural diversity. Boston: Houghton Mifflin.

Gándara, P. (2009). The Latino education crisis: Rescuing the American dream. Policy Perspectives. Retrieved November 12, 2010, from http://www.wested.org/online pubs/pp-10-02.pdf

Gay, G. (2006). Connections between classroom management and culturally responsive teaching. In C. M. Evertson \& C. S. Weinstein (Eds.), Handbook of classroom management: Research, practice, and contemporary issues (pp. 343 
-370). Mahwah, NJ: Lawrence Erlbaum. Genesse, F., Leary, K., Sounder, W., \& Christian, D. (2005). English language learners in U.S. schools: An overview of research findings. Journal of Education for Students Placed at Risk, 2005, 10(4), 363-385.

Greene, J. P. (2001, November). High school graduation rates in the United States. Retrieved May 1, 2007, from http://www.manhattaninstitute.org/html/cr baeo.htm

Grossman, H. (1995). Educating Hispanic students. Springfield, II: Charles C. Thomas.

Hollins, E. R. (1996). Culture in school learning: Revealing the deep meaning. Mahwah, NJ: Erlbaum.

Jiménez, R., Smith, P., \& Martínez-León, N. (2003). Freedom and form: The language and literacy practices of two Mexican schools. Reading Research Quarterly, 38(4), 488-508.

Johnson, N. (1980). The material culture of public school classrooms: The symbolic integration of local schools and national culture. Anthropology \& Education Quarterly, 11(3), 173-190.

Kagan, S. (1986). Cooperative learning and sociocultural factors in schools. In Beyond language: Social and cultural factors in schooling language minority students. Los Angeles: Evaluation, Dissemination, and Assessment Center, California State University, Los Angeles.

Kao, G., \& Tienda, M. (1995). Optimism and achievement: The educational performance of immigrant youth. Social Science Quarterly, 76(1), 1-19.

Krashen, S. (1981). Bilingual education and second language acquisition theory. In Schooling and language minority students: A theoretical framework (pp. 51-79). Los Angeles: Evaluation, Dissemination and Assessment Center, California State University, Los Angeles.

Krashen, S. (1982). Principles and practice in second language acquisition. Oxford: Pergamon.

Ladson-Billings, G. (2006). From the achievement gap to the education debt: Understanding achievement in U.S. schools. Educational Researcher, 35(7), 312.

Lofland, J., \& Lofland, L. (1984). Analyzing social settings (2 ${ }^{\text {nd }}$ ed.). Belmont, CA: Wadsworth.

Lofstrom, M. (2007). Why are Hispanic and African American dropout rates so high? Williams Review, 2, 91-121.

Mc Laughlin, H. J., Liljestrom, A., Lim, J. H., \& Meyers, D. (2002). LEARN: A community study about Latino immigrants and education. Education and Urban Society, 34(2), 212-232.

McLaughlin, H.J., \& Bryan, L. (2003). Learning from rural Mexican schools about commitment and work. Theory into Practice, 42(4), 289-295. McLaughlin, H. J., 
Hotch, S., \& Sargent, G. (2002). A cultural immersion experience in Xalapa, Mexico. Social Education, 66(6), 372-375.

Moll, L., Amanti, C., Neff, D., \& Gonzalez, N. (1992). Funds of knowledge for teaching: Using a qualitative approach to connect homes and classrooms. Theory into Practice, 31(2), 132-141.

Moll, L., \& Gonzalez, N. (2004). Engaging life: A funds of knowledge approach to multicultural education. In J.A. Banks \& C.A. Banks (Eds.), Handbook of research on multicultural education ( ${ }^{\text {nd }}$ ed., pp. 699-715). San Francisco: Jossey-Bass.

Mount-Cors, M. F. (2008). Bridging the differences: Cultural background of Mexican students entering U.S. schools. The University of North Carolina at Chapel Hill School of Education. Retrieved October 9, 2010, from http://www.learnnc.org//p/editions/brdglangbarriers/4486

Murrell, P.D. Jr. (2001). The community teacher: A new framework for effective urban teaching. New York: Teachers College Press.

National Center for Education Statistics (2010). The condition of education 2010. Retrieved November 11, 2010, from http://nces.ed.gov/programs/coe/2010/pdf/5 2010.pdf

National Center for Education Statistics (NCES) (2005). The nation's report card: Reading 2005. Washington, DC: U.S. Government Printing Office.

National Center for Education Statistics (NCES) (2003). Status and trends in the education of Hispanics. Washington, DC: U.S. Department of Education. Institute of Education Sciences.

National Clearinghouse for English Language Acquisition (NCELA) (2007). Retrieved September 12, 2010, from http://www.ncela.gwu.edu/files/uploads/18/MALDEF ESEAreauth.pdf

No Child Left Behind Act of 2001. $107^{\text {th }}$ Congress of the United States of America. Retrieved September 17, 2010, from http://www.2.ed.gov/policy/elsec/leg/esea02/107-110.pdf

Ogbu, J. (1994). Anthropology of education: History and overview. In T. Husen and T.N. Postlethwaite (editors-in chief), The international encyclopedia of education ( $2^{\text {nd }}$ ed., pp. 280-297). New York: Elseivier Science.

Pilon, G. H. (1987). Workshop Way Practical Handbook (Grades 2-8). New Orleans, LA: Workshop Way, Inc.

Ramírez, R. R., \& de la Cruz, G. P. (2003). The Hispanic population in the United States:March 2002. Population characteristics (No. P20-545). Washington, DC: U.S. Department of Commerce, Education, and Statistics Administration, U.S. Census Bureau.

Reyes, P., \& Paredes Scribner, A. (1995). Educational reform, students of color, and potential outcomes. The High School Journal, 78(4), 215-225. 
Richards, H. V., Brown, A. E., \& Forde, T. B. (2004). Addressing diversity in schools: Culturally responsive pedagogy. Teaching Exceptional Children, 39(3), 64-68.

Ruiz-de-Velasco, J., \& Fix, M. (2000). Overlooked and underserved: Immigrant students in U.S. secondary schools. Washington, DC: The Urban Institute.

Sañudo, L., \& Wilhelm, R. (Eds.) (2008). Diversidad cultural y educación: Una visión compartida /Cultural diversity and education: A shared visión. Secretaría de Educación Pública. Jalisco, Mexico.

Secretaría de Educación Pública (SEP). Retrieved September 10, 2010, from http://www.sep.gob.mx/es/sep1/sep1 Educacion Media Superior

Schumann, J.H. (1986). Research of the acculturation model for second language acquisition. Journal of Multilingual and Multicultural Development, 7(5), 379-392.

Sleeter, C. (2008). An invitation to support diverse students through teacher education. Journal of Teacher Education, 59(3), 212-219.

Smith, P., Jiménez, R., \& Martínez-León, N. (2003). Other countries' literacies: What U.S. educators can learn from Mexican schools. The Reading Teacher, 56(8), 772-781.

Trumbull, E. \& Rothstein-Fisch, C. (2008). Cultures in harmony. Educational Leadership, 66(1), 63-66.

U.S. Census Bureau (2003c). USA Quickfacts. Retrieved November 15, 2010, from http://quickfacts.census.gov/qfd/states/00000.html

Vasquez, O.A., Pease-Alvarez, L., \& Shannon, S.M. (1994). Pushing boundaries: Language and culture in a Mexicano community. New York: Cambridge University Press.

Vygotsky, L. (1978). Mind in society. Cambridge, MA: Harvard University Press. 